\title{
THE EAST ASIAN FINANCIAL CRISIS
}

\author{
Leslie Young \\ The Chinese University of Hong Kong
}

\section{Introduction}

After describing the major events in the regional financial crisis, I shall link them to structural problems in Asian finance. These structural problems arise from institutional limitations grounded in the culture and political economy of East Asia. The "East Asian Model" of political economy was successful in manufacturing, giving rise to triumphant rhetoric on Asian values from Asian leaders last year. I shall attempt to identify why the "East Asian Model" failed in finance. I conclude with a discussion of the dangers \& opportunities created by the regional financial crisis:

\section{The Roots of the Regional Financial Crisis}

The East Asian financial crisis can be traced back to the Japanese financial bubble of the 1980's which ended with drastic falls in Japanese stocks and real estate. This rendered effectively insolvent many Japanese companies and financial institutions. Japan never faced up to this problem, instead hiding it by accounting gimmicks and rolling over loans. While Japan had the financial depth to insulate its real economy from these problems, they undermined its ability to continue financing investment in Asia.

South Korea had adopted the Japanese model of development and succeeded only too well. With a government intent on catching up with Japanese industrialization directing bank lending toward favoured conglomerates on the basis of their contribution to national development, loan losses were hidden for decades in South Korea.

In South East Asia also, investment failed to meet commercial criteria, being characterized by corruption and vanity projects flattering to the ego of national leaders. Prominent examples were Indonesia's attempt to design and build its own passenger aircraft and Malaysia's desire to have the highest building in the world. Such investment was sustained by short-term Asian borrowing from Western banks, encouraged by low interest rates in the West and the effective peg of local currencies to the US dollar. Finally, China's successful drive to industrialization and export growth, together with its 34\% devaluation in 1994 undermined other Asian exports.

These problems together led to deteriorating balance of payments, most prominently in Thailand. Western companies then began to hedge their Asian sales revenue to repatriate profits. The requisite forward sales of Asian currencies raised local interest rates and drove down spot rates for local currencies, leading Asian companies with unhedged US dollar loans to stampede for US dollars to cover their positions. The high interest rates and illiquidity punctured regional real estate bubbles and stock markets. This was exacerbated as Asian assets were sold by Western investors who could barely distinguish Hong Kong from New Guinea. Any mutual fund associated with Asia was sold, which forced fund managers to dump stock in the most liquid markets - precisely the ones that were not in trouble, namely Hong Kong and Taiwan. This abysmal geographic ignorance on the part of Western investors, particularly in the U.S., spread the contagion to the rest of Asia. 
The resulting liquidity crisis and financial meltdown has sharply curtailed growth prospects throughout Asia. The biggest, most worrying collapse is in Indonesia, where there has been a $70 \%$ currency depreciation, exacerbated by self-serving policy responses by the Suharto regime. External trade has been halted by the collapse of export credits, internal trade by the scapegoating of Chinese merchants. Thailand, Indonesia and South Korea are now effectively wards of the IMF which has imposed severe conditions on economic reform in return for its short term financing.

\section{The Regional Financial Crisis: Structural Problems}

In contrast to Latin America, the macroeconomic fundamentals of most Asian economies were sound. Savings rates were much higher than in the West and Asian governments typically ran budget surpluses. However, in Asia, personal savings are often invested in real estate and family companies. By contrast, the bulk of Western savings are placed in pension funds, managed by mutual fund companies. This reflects structural barriers to the efficient allocation of capital in Asia.

In Asia, stock markets are often an arena for speculation, rather than a market for corporate control, as in the West. Asian bond markets account for only a small proportion of business finance because (i) the commitment to macroeconomic austerity means that the market for government bonds is poorly developed and cannot provide a benchmark for pricing corporate bonds (ii) risk loving Asian investors are unimpressed by the meager, if stable returns on bonds (iii) Asian companies are reluctant to expose their financial underwear to the extent required by international bond markets. Consequently, in Asia, most business finance is provided through banks, based on personal relationships.

\section{Institutional Problems.}

Underlying these structural barriers are institutional problems. In Asia, the regulators lack independence and democratic oversight and this reduces the credibility of their bond and stock markets. Regulatory rulings in some countries are not enforceable by the rule of law. Accounting standards are poor. There is insufficient institutional infrastructure for evaluating companies or diversifying portfolios. Even in Hong Kong, only 5\% of the population holds mutual funds. Consequently, a lot of capital is allocated politically: politicians own banks and banks own politicians.

Although Asians are bigger savers than Westerners, the poorly-developed Asian bond meant that Asians lent long to the West and borrowed short. Hence, panicked Western financial institutions could pull the plug on Asian economies, despite the West being dependent on Asian savings.

\section{Eastern v Western Political Economies}

Underlying the institutional problems, in turn, are the political economies of these countries. The Western model of political economy is based on democratic government, the rule of law and the Invisible Hand of the market. Politics and business should be kept 
separate, except in regulation to ensure predictability, accountability, transparency, and fairness in business. Within companies, the ideal is objective incentive structures and personnel procedures enforced by contract.

The East Asian model of political economy is entirely different, but has also been successful. Governments are authoritarian, but a substitute for democratic oversight is provided by the internalized sense of responsibility both of top leaders and of the civil services, which are often selected by educational attainment. The substitute for the rule of law is relationships of trust within business networks, based on family, school, dialect or regional connections. These provide a predictable environment for business: no-one would dare violate trust and lose their reputation within their business network because they would then be unable to do business.

This East Asian model was successful in converting agricultural societies into industrialized societies. Why? Because those competent, responsible authoritarians had to compete on an international arena for export markets and international investment. That led them to ensure sound macroeconomic fundamentals: low inflation, balance of payments surpluses, low interest rates. High savings rates, culturally determined perhaps, provided internal sources of capital. There was a broad commitment to basic education which provided competent, motivated labour forces. Business skills were already there.

\section{The "East Asian Model”: Failure in Finance}

East Asia enjoyed fabulously successful economic growth over the last three decades. Last year, this collapsed, along with Asian exchange rates, just as the rhetoric about "Asian values" was rising to a crescendo. Why did we have such spectacular success followed by spectacular collapse? I shall argue that both success and collapse have a common causes, which can be understood in terms of the differing roles of competition and regulation in manufacturing versus finance.

If you bought a car with a defective part, you would not buy that brand of car again and would tell all your friends. Although the manufacturers of the car and of the part may have a cosy relationship, they can't use that relationship to exploit consumers, because consumers can quickly detect quality defects and punish them both by switching to a different brand. Consequently, the market can be left to regulate manufactured goods, except in special cases like drugs where the goods might have severe irreversible effects.

Contrast this with the situation facing a financial intermediary - a bank. It lends to companies to purchase real assets. These real assets are the "inputs" of the financial intermediary, which it uses to "produce" the liabilities — bank deposits — which it sells to depositors. It is difficult for the buyers of the bank's outputs (liabilities) to detect poor quality in its "inputs" (assets) — so long as the bank can meet today's withdrawals, depositors have no reason to think there is anything wrong with the quality of their deposits.

The personal relationships which were so constructive in the development of East Asian manufacturing because they substituted for a legal framework, turned out to be highly 
destructive for East Asian financial systems. Deterioration in the intermediary's asset quality can be hidden for decades by rolling over loans to borrowers, concealing and manipulating information. Failure of intermediaries undermines general confidence in the quality of financial assets, making them all illiquid. This necessitates a public bailout to prevent collapse of financial system. Thus, Government an involuntary guarantor of intermediaries' asset quality.

To prevent this exploitation of the public requires regulators who enforce rules on financial disclosure, plus objective analysis of disclosed information by accountants and financial analysts. However, East Asia lacks democratic channels to appoint, scrutinize and discipline the regulators. Freedom of information is curtailed to maintain political stability. The accountancy and financial analysis professions are poorly developed.

\section{"Asian Values" and the Crash}

Proponents of "Asian Values" argued that Western-style democracy was inefficient in promoting economic development, whereas an authoritarian government could make decisions in the national interest, overcoming the barriers to growth thrown up by interest groups. However, authoritarian governments have unlimited reach and limited accountability, so they are constrained only by an internalised sense of responsibility. A good example of a responsible authoritarian is Lee Kwan Yew of Singapore who clearly feels a personal responsibility for the fate of Singapore. This sense of responsibility can also be seen amongst the top leaders of China, which is an important reason why China has done so well. However, this depends on a country having to good fortune to have leaders who happened to have internalised appropriate values from their culture. Since it is not supported by institutions, it is vulnerable to cronyism and nepotism. The dangers are well illustrated by Indonesia. President Suharto himself may have some feeling of responsibility for the nation, but his family members appear to have none. And Suharto gave free rein to his family.

The West also has authoritarians, namely regulators and judges. In recognition of democracy's inefficiencies in processing information to arrive at decisions on complex issues like exchange rates, interest rates or the allocation of rights to carry out economic activity, qualified individuals are given authoritarian powers. Don Brash could change New Zealand's interest rates tomorrow and there's not much we can do about any particular decision. However, he is constrained by rules which (i) require him to exercise his authority only in pursuit of well-defined objectives, and (ii) define procedures for reviewing his performance and re-appointment to office. He could even be taken to court if he violated his mandate or exceeded his authority. So his authority is institutionally constrained.

Why this difference between East and West? The assumption in Asian cultures, and also on the European Continent, is that people are fundamentally good, or at least perfectible. This touching belief gave you Marxism, Fascism, the Killing Fields of Cambodia and other modern disasters. By contrast, Anglo-American political economy incorporates a high level of scepticism about people in power. Its institutions assume that people are fundamentally 
nasty and sleazy, and need to be institutionally constrained. So it creates limited authoritarians.

This approach also has its problems, such as capture of the regulators by those who are regulated and the manipulation of the appointment process by vested interests via campaign contributions. However, on current evidence, the Anglo-American model of political economy is best suited to a global economy open to international financial flows.

\section{Dangers and Opportunities}

Financial collapse in Asia has reduced income growth and demand there. There is a danger of increased protectionism as interest groups struggle to maintain incomes, of a moratorium on debt payments and restrictions on international capital flows. The worst-case scenario is a wholesale rejection of the institutions which have supported the global economy.

On the plus side, the financial collapse in Asia could also lead to a demand for greater openness, accountability and transparency to ensure continued growth. It challenges aspects of Asian Model which had been exploited to justify government interference and cronyism. Thus, it could point the way to a creative synthesis of Western and Asian institutions.

\begin{tabular}{|l|l|l|}
\hline & \multicolumn{1}{|c|}{ DEMOCRATIC } & \multicolumn{1}{|c|}{ AUTHORITARIAN } \\
\hline SOCIALIST & $\begin{array}{l}\text { India, Australia, New } \\
\text { Zealand }\end{array}$ & $\begin{array}{l}\text { China, Burma, Vietnam, } \\
\text { North Korea }\end{array}$ \\
\hline FREE MARKET & Philippines, Thailand & $\begin{array}{l}\text { South Korea, Taiwan, } \\
\text { Singapore, Hong Kong }\end{array}$ \\
\hline
\end{tabular}

In deciding which outcome is more likely, consider the table below which distinguishes the development paths of some Asia countries along just two dimensions: political and economic organization. Few observers would have chosen the winners in the bottom left corner of the table in the aftermath of the Second World War. After all, the most prosperous countries in Asia were then Burma and the Philippines. However, as the winners became clear, losers started adapting lessons from the winners.

Today, many experiments are again being run in Asia. As the results become clear the region shall again adopt the models of political economy which are found be most successful. The driving force shall be competition - between countries. Countries in the region share the objective of economic growth to secure political legitimacy; to achieve this, they must compete on international markets, not only to export, but also to attract investment. To do that they must develop transparent, credible regulatory systems in finance. Hong Kong and Singapore have such systems, which have stood them in good stead through the current crisis. Other countries in the region can see and learn from that. 